\title{
National Universities in Argentina during the pandemic outbreak
}

\begin{abstract}
Author:
Mariana Mendonça $a^{1,2}$

\section{Affiliations:}

${ }^{1}$ Institute of Argentine and American History 'Dr. Emilio Ravignani', Department of History, Faculty of Philosophy and Literature, University of Buenos Aires, Buenos Aires, Argentina
\end{abstract}

${ }^{2}$ National Council for Scientific and Technical Research (CONICET), Buenos Aires, Argentina

\section{Corresponding author:} Mariana Mendonça, mmendonca85@gmail.com

\section{Dates:}

Received: 07 Aug. 2020 Accepted: 02 Oct. 2020 Published: 02 Nov. 2020

How to cite this article: Mendonça, M., 2020, 'National Universities in Argentina during the pandemic outbreak', Transformation in Higher Education 5(0), a91. https:// doi.org/10.4102/the.v5i0.91

\section{Copyright:}

C 2020. The Author. Licensee: AOSIS. This work is licensed under the Creative Commons Attribution License.

\section{Read online:}

Background: The health emergency that Argentina is experiencing because of the COVID-19 pandemic radically changed institutional normality at all educational levels. Universities have certainly not escaped this logic. Whilst their first response was a general shut down, along with a shift to online teaching and learning, the actions taken in response to the pandemic went far and beyond. These institutions sought to contribute, in different ways, to satisfy the new social demands linked to the outbreak of the health emergency.

Aim: We aim to give an account of the actions that the national universities in Argentina took in response to the distinctive social demands linked to the pandemic outbreak.

Setting: Specifically, we focussed on the academic and pedagogical decisions, the reorientation of scientific research, the availability of infrastructure and resources for the COVID-19 treatment and the responses to the social demands of local communities.

Methods: We worked with institutional documents from the national universities, the National Inter-University Council, the Ministry of Education and the Ministry of Science and Technology. We also used news sources, such as newspapers articles and the universities web sites.

Results: Our research brought the attention to some interesting facts on the country's higher education system, which shows us a distinctive role that universities play in Argentina. Nevertheless, we have also found indicators regarding the difficulties that these institutions struggle with. In particular, these linked to the economic crises that the country has suffered for decades, which in turn have changed the universities specific features.

Conclusion: The COVID-19 pandemic disrupted the functioning of society as a whole, and universities were no exception. Despite the strong heterogeneity that characterises national universities throughout the country, all of them agreed to make all their resources available to mitigate the effects of the health emergency.

Keywords: university; higher education; Argentina; pandemic; COVID-19; social demands; research; online teaching.

\section{The higher education system in Argentina}

Since the mid-twentieth century, Argentina's higher education system has undergone different waves of expansion and transformation. The university map shows today 131 institutions spread all over the country. Amongst them, 66 belong to the public sector, 63 are privately managed and the other two are foreign ones. Despite the similar number of institutions in the private and the public sector, it is worth highlighting that the public sector holds $79 \%$ of enrolment in the country, that is, 1500000 students approximately. ${ }^{1}$ Unlike other Latin American countries, the private sector in Argentina never reached more than 20\% of enrolment (Ballerini 2018). One of the main explanations of this characteristic is that the core policy since 1950 has been tuition-free and open access in the public system (with political interruptions until 1983, when the establishment of free tuition was definite). ${ }^{2}$ During the eighties and nineties, enrolment grew mainly in traditional universities, most of them based in large urban centres. ${ }^{3}$ Once again Argentina went through an expansive wave of higher education institutions and by the mid-1990s, the number of universities

1.For detailed statistical information, see http://estadisticasuniversitarias.me.gov.ar/\#/home.

2.Under Juan Domingo Peron's government, all restrictions to access were removed, tuition fees were eliminated in 1950 and in 1953 so were all the entrance exams. This led to an explosive growth in the public universities enrolment. Two coups d'état tackled this trend in 1966 and in 1976, respectively. After the fall of the last Military Junta (1976-1983), which had triggered a severe contraction in enrolment as a direct result of the repression unleashed upon students and the implementation of admission courses, the number of enrolment as a direct result of the repressio
incoming students grew strongly again.

3.While until 1956 Argentina had eight national universities in some provinces, by 1975 there were already 25 national universities in different parts of the country, which allowed for this growth to take place. 
had gone up to 35 and the number of enrolees surpassed 800000 (Mendonça 2020).

Although undergraduate tuition is free, since 1996 the national government has implemented different grant programs to support other educational costs, such as books, transportation and class materials, whether per diem or by a monthly sum. These policies respond to the rise in the poverty and unemployment rates that took place in the nineties: while the former grew up to $30 \%$, the latter doubled its initial number, reaching a peak over 20\% in 2002 (Acuña, Kessler \& Repetto 2002). In this scenario, free tuition did not necessarily imply free and open access. Hence, the public university system tried to catch up to new demands, mainly related to a new social-student profile.

Low-income sectors are today the largest and most dynamic segment of enrolment expansion. Many university students are already employed or are actively seeking employment, and nearly $20 \%$ of them are heads of household. Likewise, there are a significant number of students who have graduated from special government programs aimed at the completion of secondary school. These students are generally young mothers from impoverished neighbourhoods, teachers or adults who had postponed their studies to work. Most of them are making significant progress in comparison to their parents, since they represent the first generation of university students in their family and even the first generation of highschool graduates. Many of these students were able to access university education in the framework of university expansion policies that took place during Cristina Fernández administration (2007-2015) (Mónaco 2017). In those years, a third expansion wave took place and several institutions were established across the country, eight of which were based in Buenos Aires's suburban areas. We should underscore the fact that $20 \%$ of the total population of Argentina lives in Buenos Aires province (INDEC 2010), a territory that has historically been characterised by being home to a significant section of the population living in poverty, with unfulfilled basic needs and high levels of unemployment.

These universities were aimed at reorienting Argentina's economy towards diversification and complementation of the national productive structure, contributing to regional and national development (García Delgado \& Casalis 2013). In general, their institutional projects focused explicitly on the linkage between local, regional and national development. Indeed, the academic offerings and the lines of research proposed are oriented towards the establishment of a direct link with the local environment, seeking to contribute to areas considered as priorities: production, technology, environment, health, social economy, management and public services, amongst others.

One of the main characteristics of these new universities' set of objectives is that they aim to review practices and the ways in which they relate to their social environment. In particular, they seek to promote the type of research that contributes to the resolution of problems affecting the population, implement non-university education programs around subjects relevant to the local community, engage in cultural activities of community integration and encourage - on the basis of knowledge acquired in university - the development of media campaigns to help the community and activities to improve their living conditions. Thus, new universities, and particularly those based in Buenos Aires's suburban areas, have developed a network of social inclusion that transcends academic training, something that has been mainly accomplished through outreach programmes. This feature has been conceptualised by international literature as a 'third mission' for higher education institutions, which includes all those activities that escape academia and that are related to the production, use, application and exploitation of knowledge and other competencies at the disposal of universities (Molas-Gallart et al. 2002). In Argentina, this socalled third mission not only refers to the transfer of knowledge and technology but also to 'university social responsibility', which encompasses proposals like the ones mentioned above. This is a clear indication that we are before a reinforcement of this role in the university system. Within this framework, universities have experienced some changes in their functions and have acquired a significant role in development processes (CIN 2012).

\section{Universities within their territory}

The linkage between universities and their surrounding territory is not new in the history of Argentina's higher education system. On the contrary, the need to reinforce the ties with non-university actors began to gain importance amongst the academic community at the beginning of the 20th century. In particular, community outreach programmes have been identified to be crucial for the transformations brought about by the 1918 University Reform (Labrandero \& Santander 2008; Tünnerman 2000). The desire to integrate university life into the community gave rise to this 'social responsibility', which distinguished Latin American institutions from those in other parts of the world (Tünnerman 2000). The question that arises, then, is what makes these new national universities (in particular those created in the Buenos Aires suburbs) different from the others when it comes to their linkage with the territory?

As we have already mentioned, we must point out their geographical location: a significant fraction of Buenos Aires suburbs is marked by strong social deterioration. A large part of the population has Unsatisfied Basic Needs (NBI), including housing, education, labour and health deficits. As Suárez and Palma Arce state, these conditions determine the strong heterogeneous structure that characterises the Buenos Aires suburbs, which is expressed, in turn, in social and territorial fragmentation and segmentation (Suárez \& Palma Arce 2010). It is within this context that we must analyse these new universities.

One of the most notable features of these institutions was the magnitude of the enrolment, driven mainly by students coming from the surrounding areas. In particular, as we have 
mentioned, the low-income sectors now represent the most dynamic segment of enrolment growth. On the other hand, Science and Technology policies, as well as linkage and technology transfer actions, have also generated important results during the first decade. In this sense, Thomas (2015) states that the role of Science, Technology and Innovation in providing solutions to problems regarding poverty and social exclusion has become a highly relevant issue in the academic field, and that it yields useful results for public management. This has been expressed in the orientation of activities, budgets and teaching staff towards the development of applied research in strategic sectors, as well as extension and transfer policies aimed at local governments and economic actors in the local territories (García Delgado \& Casalis 2013).

In particular, universities are constantly trying to respond to the social demands of the local population, and permanent strategies are being developed. While it is not the aim of this article to give an account of these processes, we do believe that it is important to shed light on some lines of action in order to later understand how they managed to adapt immediately to a national health challenge such as COVID-19.

The research lines, the outreach programmes and technology transfer activities that these universities carry out are based on situated knowledge. In other words, the production of knowledge is carried out through a direct link with the recipients. Thus, for example, if we look at the addressee of research and/or transfer projects of the new universities in the Buenos Aires suburbs, we find that in 2017, more than 50\% was oriented towards social transfer, including local governments, businesses, social organisations, other sectors of local, regional or national administrations and the community in general (Roca, Schneider \& Pedrosa 2018). Amongst the most outstanding issues, we find them related to community health, environmental management, environmental health, occupational health, urban development, mobility, habitat, industrial design and support to small producers through, for example, research in areas such as biotechnology.

This eagerness to put in motion activities in the territory and establish inter-institutional links distinguishes the new universities from the 'traditional' ones (Roca et al. 2018). ${ }^{4}$ However, it should be mentioned that the former have a strong budgetary disadvantage.

In sum, it has been possible to set up research groups and develop lines of research, outreach programmes and

\footnotetext{
4.The "traditional' universities have been, historically, the first institutions of highe education that were created in the country, that is, the National University of Córdoba and the University of Buenos Aires, both of them with strong Napoleonic roots. Since then, new universities have been created aiming to be different from the latter. Thus, the institutions that were created during the first decades of the 20th Century intended to resemble the German Humboldt model, with a solid research profile. By the mid-fifties and seventies, the United States model was research profile. By the mid-fifties and seventies, the United States model was dominant. Despite the fact that the 16 new national universities that were created between 1971 and 1975 were sought to emulate the Anglo-Saxon model, a few years after the first wave of expansion, most of them had traditional feature (Mendonça Forthcoming). During the nineties and the first decades of the 21st Century, new national universities were created, aiming, once more, to differ from the traditional profile. Although they have been created in different moments, and under different political regimes, all of them are national, tuition-free universitie and their core functions are teaching, research and outreach activities.
}

technology transfer programmes with local communities. On the basis of strengthening the link between universities and the territory, these new institutions have also been able to offer an articulated response to the emergence of the COVID-19 pandemic.

In this article, we will underscore the actions developed by the national universities in the country in order to address the social demands that emerged in the pandemic outbreak. As we have mentioned, since the 1970s the system has undergone three expansion waves and today there are more than 50 national universities spread all over the country. The ones created in the seventies sought to emphasise a regional profile and were built, mainly, in different provinces. During the nineties, the universities were established in Buenos Aires' suburban areas and it was expected that this would decentralise enrolment in old traditional universities (the University of Buenos Aires and the national University of La Plata). The last wave of expansion took place a decade ago and universities were created in different provinces, but were mainly created in the Buenos Aires suburbs. All of them have responded in different ways to the pandemic. It is our aim to give an account on their actions.

\section{Research methods and design}

The main research questions aimed to explore how the pandemic outbreak impacted universities activities and the role that they play in the Argentine society. In the first place, we have used scholarly second-hand sources to approach the general economic and health context in the country, as well as to give an account of the main characteristics of the higher education system. In order to analyse the impact of the pandemic outbreak on university activities, in the second place, we collected the information through institutional sources, such as the national universities, the National InterUniversity Council (CIN), the Ministry of Education and the Ministry of Science and Technology. Given the quarantine context, these sources were collected from the institutions websites. All of them have been published since March and were consulted from that date to the end of August 2020. We also used news sources from five different national newspapers: La Nación, Clarín, Página/12, Infobae and Ámbito. These were also consulted online, and their use is merely informative and by no means aims at analysing different points of view. On the contrary, we have consulted these sources in order to give an account on the information regarding national universities in the pandemic on a daily basis. Considering that most of these media published the same information, we have selected the newspaper articles that had addressed the topic in-depth and covered all aspects of the subject. When necessary, we have also used online media to support the information.

\section{Ethical consideration}

This article followed all ethical standards for carrying out research without direct contact with human or animal subjects. 


\section{Results}

Our research brought the attention to some interesting facts on the country's higher education system. As we will present in detail in the following sections, universities have managed to respond in different ways to the health emergency. In the first place, the shift to online teaching and learning involved a massive restructuring of the teaching activities: not only did teachers need to learn to use many Information and Communications Technologies and to adapt their classes to a virtual environment, but students were also required to engage with this new system. Secondly, many universities put their research teams and infrastructure at the service of the community to respond to different demands, that is, the prevention of new infections, the reorientation of research teams into new treatments, the rehabilitation of recovered patients and the increase of the health system capacities. Finally, various actions have been carried out in relation to social problems, such as food, health and clothing, triggered by the pandemic at a local level.

While this shows us a distinctive role that universities play in Argentina, we have also found indicators regarding the difficulties that these institutions struggle with. In particular, these linked to the economic crises that the country has suffered for decades, which in turn have changed the universities specific features.

\section{COVID-19 and the new challenges faced by Argentine universities}

On March 20, in response to the local outbreak of the pandemic, the national government issued a decree ordering a general social confinement in order to prevent and reduce the spreading of the virus and mitigate its impact on the health system. In this context, most of the population had to remain in their homes, abstaining from going to work or moving around locally and regionally and avoiding public places and social meetings.

In this context, public universities began to gain space in the design and implementation of strategies linked to the containment of the virus, reducing the spread of the pandemic and researching into medical treatments, as well as the design of strategies to implement virtual teaching methods. This role was foreseen by the Minister of Education, Nicolás Trotta, at a meeting held with the Executive Committee of the CIN, where he stated that: 'We have to prepare ourselves for an unknown scenario and that is where we believe our universities will be able to play a leading role' (CIN 2020a).

As mentioned above, the whole education system went through a general shutdown after March 20th. ${ }^{5}$ However, one of the first actions carried out by the national universities was the implementation of a framework agreement signed summer classes during February, start their first semester during mid-March o April. by the CIN and the Ministry of Education in order to produce and broadcast educational content. The objective of the agreement is that these institutions provide the entire educational system with means and infrastructure necessary for the production of educational and cultural content in different formats, that is, radio, audio-visual and editorials. According to the CIN, this should enrich the content and proposals that are being made available to the country's students (CIN 2020a). In addition, universities collaborated with prevention campaigns, information and brochures of the pandemic.

A few days later, a survey of the infrastructure capacities of the public university system in relation to the pandemic began, which included the availability of beds in university hospitals and the scientific and technological capacities for the production of inputs (CIN 2020b). In particular, some universities contributed to the manufacture of alcohol gel and 3-D technology printing of protective masks for health personnel. Others redirected the lines of research of their working groups, which had concrete results of great importance.

The following is a description of the different actions that were carried out in response to the health emergency. To do so, we will work with the four proposed themes: academic and pedagogical decisions, reorientation of scientific research, availability of infrastructure and resources for the COVID-19 treatment and responses to the social demands of local communities.

\section{The shift to online teaching and learning}

After the general shutdown, universities worked against the clock to ensure the academic year. While the undergraduate programmes in public universities in Argentina are mostly face-to-face classes, the pandemic outbreak forced a shift to online classes. However, as Marquina (2020) states, Argentina has an advantage regarding distance education. At the turn of the century, it began to expand at a fast pace, and in 2017 the university sector as a whole signed a framework agreement for distance education, grounded on with the same quality standards as face-to-face education. To this end, the CIN, together with the Office of University Policies (SPU) worked on a regulatory framework to specify quality requirements for distance education. This, in turn, resulted in a new beginning for distance education in Argentina's public universities. Since then, each university has had to set up its own Institutional Distance Education System, and subsequently get assessed by the SPU and by the National Commission for University Evaluation and Accreditation (CONEAU). This evaluation process documents the universities functional structure, technological infrastructure, specialised human resources, teaching strategies and research activities on this type of education. Although most academic offerings are face-to-face programmes, as Marquina (2020) points out, the university system relays on a structure that is prepared to face this kind of contingencies. 
Nevertheless, setting up a virtual academic year for the whole system at the beginning of a pandemic outbreak presents several problems. For instance, virtual platforms had to be set up in a record time, teachers without the necessary pedagogical skills had to prepare virtual classes against the clock, learn how to use the platforms, be able to digitalise documents and books for the students and organise their work shifts in order to fulfil the requirements both at home and in class. All of these, at some point, were taken care by the technological staff. But another key issue was soon identified: do all students have access to a computer, a cell phone or a tablet? Do they count with network connectivity?

Argentina has over 40 million inhabitants. Throughout the country, there is a strong heterogeneity when it comes to living conditions, especially in cities that are distant from the urban centres. The Buenos Aires suburbs stands out, since a quarter of the country's population lives in this area and approximately 4 million (34.1\%) are poor, that is, their total incomes do not cover food and basic services for a daily reproduction (Beccaria n.d). In this scenario, it is not surprising, then, that access to the Internet and electronic devices has emerged as problems to be solved in order to ensure pedagogical continuity. As a first step, the national government made an agreement with the wireless communication service companies, facilitating free access to the university virtual platforms. Despite that, students were not able to assist to the virtual classes online, since most of them were not undertaken in the university platforms, but were taken in other cloud-based videoconferencing services. Some universities, thereupon, decided to create grant programmes in order to provide internet services to their students. At the same time, some of them decided to lend computers to students until the end of the quarantine. Nevertheless, national universities experienced a high level of dropouts during the first semester. ${ }^{6}$ Although dropouts during the first academic year are common in Argentina's university system, we may expect an increase with the pandemic outbreak, despite all the efforts made by the government and the university authorities.

That said, even though Argentina is technically prepared to respond to this contingency, it still presents an enormous challenge given the heterogeneity, poverty and inequality of its population. ${ }^{7}$ The pandemic outbreak brought to light one of the main problems that the university system in the country has: in spite of the open access and free tuition, universal higher education still remains unmet. ${ }^{8}$

6.Although a rigorous analysis of university statistics needs to be done in order to compare dropout rates before, during and after the pandemic in Argentina, it is possible to trace some interesting data. See, amongst others Dal Piva (2020) and Achigar (2020).

7.For detailed information on Latin American Higher Education systems during the pandemic, see UNESCO-IESALC (2020)

8. For more detailed analysis on this topic, see amongst others, Chiroleu and Marquina (2017).

\section{Scientific research}

Argentina has a strong tradition in scientific research and technological development, which was historically performed by universities. Compared to other countries in the region, Argentina has achieved early and satisfying results in this matter.

In the early twentieth century, the first research groups that were recognised as such were located in the public national universities. Although over the years other private- and public-scientific institutions emerged, national universities still hold most of the ongoing investigations. More than $60 \%$ of the 50000 people who conduct science and technology activities in Argentina work at public national universities (Albornoz 2004). With the outbreak of the COVID-19 virus, the scientific system was put under further strain.

One of the first measures at the national level was the creation of the 'COVID-19 Coronavirus Unit', aimed at responding to the immediate demands and needs of the executive branch and the Ministry of health. To do so, the National Council for Scientific and Technical Research (CONICET), in cooperation with the Ministry of Science, Technology and Innovation and the National Agency for the Promotion of Research, Technological Development and Innovation (Agencia $I+D+i)$, presented the guidelines to develop projects aimed at improving the national capacity to respond to the pandemic in the country (CONICET 2020c). With an investment of $\$ 5$ million, these organisms and agencies financed 64 research projects, most of them were carried out in public national universities. Amongst these, many extremely valuable developments in prevention and diagnosis should be highlighted.

In the first place, three different COVID-19 tests were developed by scientists at public universities or public health institutions, either by their own or allied to private firms. One of those, the 'Neokit-COVID 19', is a diagnostic test for the simplified molecular detection of the SARS-CoV-2, the etiological agent of COVID-19, which was designed by CONICET researchers at the César Milstein Science and Technology Institute, along with researchers at the San Martin and the Quilmes national universities. Instead of the polymerase chain reaction (PCR) technique, it relies on loop-mediated isothermal amplification (LAMP) for ribonucleic acid (RNA) amplification. This makes it as reliable as the other one, but it is quicker (the results are delivered in less than $2 \mathrm{~h}$ ) and cheaper. As a matter of fact, it can also be mainly manufactured with local components, which is particularly important in Argentina, because of the fact that the costs of imported products are extremely high. Another advantage is that the lab test is simpler, and therefore it does not need to be operated by highly-trained personnel. In a similar fashion, the ELA-CHEMSTRIP test, jointly developed by researchers at San Martin National University and Quilmes National University and technological firms, operates with easy loop amplification (ELA) and offers 
similar advantages as the other one. Besides, a serological test was also jointly developed by researchers from CONICET and the Leloir Institute, a public health institution. The COVIDAR IgG, aimed to test for the presence of COVID-19 antibodies, is based on the ELISA technique and offers high sensibility and quick results at a low cost (ámbito 2020; Bär 2020c; CONICET 2020a, 2020b; Infobae 2020; UNQUI 2020; Zamponi 2020). Besides, it not only gives information of the presence of antibodies but can also quantify them, a crucial information regarding the identification of potential plasma donors (UNSAM 2020).

In the second place, an anti-COVID-19 hyper-immune serum for passive immunisation was developed recently as a result of a joint effort by the San Martín National University and the private sector. This therapeutic serum contains a large number of antibodies with neutralising capacity. Via in vitro tests, the serum has shown the ability to neutralise the SARSCov-2. It could prevent the virus from entering the cells where it multiplies (Buenos Aires Time 2020). Besides, the Buenos Aires University led the first trial of the use of cured patients' plasma for severe COVID-19 cases, and later allied to a private health firm in an effort to multiply plasma donors (Bär 2020c; Sigal 2020).

In the third place, researchers at the Leloir Institute and the San Martín National University joined forces to develop a vaccine against COVID-19. The project is still in pre-clinical phase, and an alliance with private firms is expected in order to move on to the next phases. While this development is lagging behind many other vaccine trials around the world, the researchers are attempting to produce a vaccine version that could be orally administered, therefore not requiring trained personnel for its application (La Voz 2020).

Lastly, researchers from CONICET, the University of Buenos Aires and the National University of San Martín have created facial masks using a technology that deactivates the COVID-19 virus in $5 \mathrm{~min}$. These researchers developed fabrics treated with antiviral, bactericidal and fungicidal agents to manufacture, amongst other things, face masks. The fabrics properties were successfully tested by the National Institute of Industrial Technology (INTI), and are now marketed under the brand name Atom Protect (CONICET 2020c).

We must point out that these are developments that were possible precisely because of previous investment in technology and training of qualified workers over the years. Although the country's scientific system has not fully recovered after the military coups in 1966 and in 1976, ${ }^{9}$ after

9.The scientific system, including research performed at national universities, started growing during the 1950s. However, the Military regime that came to power in 1966, led by General Juan Carlos Onganía, took over the national universities, which were believed to be loci of communist activities. Hence, political repression was widely carried out, resulting in violent events such as La noche de los bastones largos (The night of the long sticks), where the police entered into the University of Buenos Aires and hit students and professors alike. Ten years later under another coups d'état, as Bekerman (2018) states, the scientific institutions underwent strong discipline process which included strict ideological control and the expulsion
of professors and researchers for political reasons. Universities underwent budget the return to the democratic and constitutional government in 1983, scientific research has been driven by national policies although with variable strength. Therefore, today it has a long tradition and counts with different research teams that have been working in different research areas. Thus, with the pandemic outbreak, national universities were able to reorient their lines of work to meet the new health demands.

\section{Infrastructure and resources}

As Marquina (2020) states, since March national universities have become leading players in the fight against COVID-19. Many institutions started producing items in short supply, such as alcohol-based hand sanitiser and masks, as well as ventilators and other hospital supplies. The institutions that have medical schools are also carrying out tests to diagnose the disease in their university hospitals or laboratories; the ones who do not, they have prepared their headquarters to be used as field hospitals if necessary. At the same time, all of them have recruited volunteers to assist patients, give support to elderly living alone and to work hand-in-hand with different activities of local governments to mitigate the disease. It is not our intention to list all the activities that these institutions started during the outbreak, but we can mention some of them as an example. Medical students, that is, future doctors and nurse practitioners, amongst others, held flu vaccination rounds all over the country. Students enrolled in other university careers volunteered in control tasks in order to guarantee that all medical supplies would reach destination. Others started working at call centres specifically set up to monitoring persons who have been in contact with the virus.

Nevertheless, the pandemic has significantly increased the requirement of health professionals. Enrolment in medicine careers, especially M.D., has been historically massive in Argentina. So much so that in some periods, it has become a problem and a lot of reports have proposed redirecting enrolment to careers considered to be a priority, for example, Engineering and Technology. In the last few years, degrees other than M.D. arose as priorities within Medical School: nurse practitioners, physiotherapy, physiatrist, obstetrician, amongst others.

Immediately after the outbreak hit Europe, and then Latin America, one of the main problems appeared to be the need to increase the number of available ventilators, which are used in the most severe cases of the illness. The first response, in turn, was importing and producing local ones. Some universities in Argentina, in the framework of the COVID-19 Coronavirus Unit, developed a project that aimed to improve the capabilities of mechanical ventilators and allow the

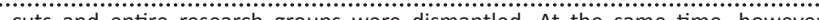
CONICET went through a contradictory process, wheres an initial restriction was follow we budgetry, institutional and human resource expansion. This, in tu followed by budgetary, institutional and human resource expansion. This, in turn, lead to a clear division between teaching and research activities, mainly restricting teaching and learning in universities (Bekerman 2013). 
simultaneous ventilation of two patients. But as Garofalo states, ventilators do not operate themselves.

Even as the production of ventilators catches up with the unprecedented demand around the globe, ventilators still need skilled - and physically and psychologically healthy - staff to operate them properly. One ventilated patient requires at least two healthcare professionals per shift. The pandemic has made the already existing shortage of trained ICU personnel become more evident. (Garofalo 2020)

As a matter of fact, Intensive Care Units (ICU) include not only doctors and nurses but also physiotherapists.

An initial response from the national government and the Office of University Policies was to expedite the issuance of university degrees. In Argentina, it is not uncommon that degrees are issued long time after graduation, sometimes more than a year. During the pandemic, universities managed to speed up the process to just a few months. Besides, to be able to practice, health professionals must pay a required fee in order to receive their medical license. Accordingly, some universities created grant programmes to support them and increase the health staff. It is worth mentioning that, in Argentina, nursing students often belong to the most economically-disadvantaged groups.

In this health emergency scenario, physiotherapists became key professionals, because of the fact that one of the discipline specialties is respiratory rehabilitation. This specialty has existed since the mid-fifties, when Argentina went through the polio epidemic. Today there are around 1200 specialists, many of whom are graduates from the Argentine Society of Intensive Care (Página/12 2020). Patients who recover sufficient lung capacity to be disconnected from the ventilator must recover their muscular strength, achieve autonomy to be able to eat and drink and overcome possible sequelae associated with the use of the ventilator (Página/12 2020). Because of this, the Ministry of Health of the Province of Buenos Aires carried out a call for additional hospital staff, seeking to incorporate 500 physiotherapists to public hospitals. At the same time, one of the universities in the Buenos Aires suburbs recently inaugurated a respiratory rehabilitation centre to attend patients recovered from COVID-19 who have respiratory sequelae (Perfil 2020). This demand would have been much harder to satisfy without expediting the issue of degrees.

\section{Social demands}

While the confinement allowed slowing down the rise of contagion, its flip side was a fall in production, the growth of poverty and in the number of people in a state of emergency (ONU 2020). Between 2005 and 2011, Argentina's economy expanded at an annual rate of 5.7\%, but between 2012 and 2019 it withdrew to an average rate of $2.5 \%$. These cycles of expansion and retraction in the economy are characteristic of the country (Salvia \& Poy 2020). Since 2018, however, this period of stagnation or recession turned into a structural crisis, which would be aggravated by the pandemic: in 2020, the gross domestic product (GDP) is expected to shrink around $10 \%$. The confinement has a severe impact on different economic activities. According to the International Labour Organisation, the most compromised activities are those related to business, construction, manufacturing, tourism and transport, hotel and restaurant activities, as well as personal services and household employment. It must be noted that these activities employ $70.1 \%$ of the country's urban labour force (Salvia \& Poy 2020). Besides, a great portion of workers are not registered or are in a precarious situation. In many occasions, this means that they are not able to earn their wage if they cannot go to work.

In this scenario, the Argentine government took several measures to compensate the collateral consequences that the pandemic outbreak brought. Amongst them, we can point out the budgetary enforcement for school meals and community dinners, and an increase in different socialprotection programs, amongst others.

Universities, for their part, were also active in the government's response to social demands. One of the most relevant actions regarding the economic scenario was the Solidary Funds Programme. The project is aimed at assisting the district's community dinners, school dinners and clubs. It is worth highlighting that, since the nineties, the most impoverished fraction of population's diet is mainly subsidised by the government. After the economic crisis in those years, schools also offered a place for setting community dinners, and some of them succeeded in reducing dropouts, thanks to these actions. Many students went to school so they could have at least a daily meal. During this pandemic crisis, schools started handing out rations of food for all family members. To this end, universities have strengthened efforts in order to assist them. Members of the academic community have agreed that a percentage of their salary is voluntarily deducted. The aid consists in boxes of non-perishable food and cleaning supplies. And at the same time, it involves students, professors and staff in voluntary work (UNAHUR 2020a; UNGS 2020; UNPAZ 2020).

Other actions were also carried out to support the workers of the local communities. The National University of Hurlingham, for example, used to offer a bike lending service to their students. As they are not assisting to the campus during the outbreak, the service was redirected to students who work in the surroundings, who can borrow the bikes if they need to work outside their houses instead of cramming into public transports, one of the main focal points of contagions (UNAHUR 2020b).

\section{Final words}

Historically, Argentine public universities have been a place of knowledge production and development of research lines, 
with a strong interest in establishing links with society. University outreach, as we have mentioned, dates back to before the 1918 Reform and has been modified, adapted and extended over the years. The link with the territory and with the local populations, consequently, was strengthened from the different substantive functions of these institutions. Besides teaching, research, transfer and outreach programmes, Argentine universities today have a myriad of actions that respond to different social demands. Today we find universities with a strong social commitment, which includes the territory and local populations in their institutional projects.

The COVID-19 pandemic disrupted the functioning of society as a whole, and universities were no exception. However, the social purpose of these institutions was expressed in every possible way. Despite the strong heterogeneity that characterises national universities throughout the country, all of them agreed to make all their resources available to mitigate the effects of the health emergency. Perhaps the greatest attention has been paid to the academic calendar, whether or not pedagogical continuity could be guaranteed, as well as issues related to the quality of teaching in a virtual environment, and even discussions about assessments have been the focus during the first semester. But not everything was limited to training and teaching activities. On the contrary, the research teams, where possible, redirected their scientific progress and succeeded in developing products to be used in the prevention, diagnosis and treatment of COVID-19. Others started to use already existing technologies to be able to produce input elements for the health service, the production of masks with 3-D technology and the production of gel sanitiser, are just some of them. Agreements with privately managed laboratories were also of great importance in order to advance in these developments. Likewise, the framework projects and the agreements with the local governments allowed strengthening prevention actions with the local populations.

In sum, the health emergency and the social isolation were far from paralysing university activities. Not only did they accomplish to advance in actions to mitigate the COVID-19 but also were able to redirect the different research lines. Even young universities, created during the last decade, put all their resources at the service of the population in order to counteract the effects of the pandemic.

\section{Acknowledgements Competing interests}

The author has declared that no competing interests exist.

\section{Author's contributions}

The author declares that she is the sole author of this research article.

\section{Funding information}

This study received funding from the National Council for Scientific and Technical Research (CONICET).

\section{Data availability statement}

Data sharing is not applicable to this article as no new data were created or analysed in this study.

\section{Disclaimer}

The views and opinions expressed in this article are those of the author and do not necessarily reflect the official policy or position of any affiliated agency of the author.

\section{References}

Achigar, S., 2020, 'El acceso a la universidad en tiempos de pandemia', La Izquierda Diario, 07 July, viewed from https://www.laizquierdadiario.com/El-acceso-a-laUniversidad-en-tiempos-de-pandemia.

Acuña, C.H., Kessler, G. \& Repetto, F., 2002, Evolución de la política social argentina en la década del noventa: Cambiosen su lógica, intencionalidad y en el proceso de hacer política social, Center for Latin American Social Policy - CLASPO - University of Texas at Austin, Buenos Aires.

Albornoz, M., 2004, 'Política científica y tecnológica en Argentina', in Globalización, Ciencia y tecnología, vol. II, pp. 81-92, Organización de Estados Iberoamericanos para la Educación, la Ciencia y la Cultura (OEI), España.

ámbito, 2020, Investigadores argentinos desarrollaron un suero terapéutico anti coronavirus, viewed n.d., from https://www.ambito.com/informaciongeneral/covid-19/investigadores-argentinos-desarrollaron-un-suero-terapeuticoanti-coronavirus-n5110656.

Ballerini, V., 2018, America's promise and Argentina's unrestricted access: A comparative analysis of equity implications of tuition-free and open-access models in Higher Education, Higher and Postsecondary Education Department of Administration, Leadership and Technology, New York, NY.

Bär, N., 2020a, 'Coronavirus en la Argentina. Crean un test bien "criollo" para detectar Covid-19', La Nación, 13 Junio, viewed n.d., from https://www.lanacion.com.ar/ ciencia/coronavirus-argentina-crean-test-bien-criollo-detectar-nid2378973.

Bär, N., 2020b, 'Coronavirus en la Argentina: La ciencia local entra a jugar contra el Covid-19', 18 Marzo, La Nación.

Bär, N., 2020c, 'Coronavirus en la Argentina: Preparan un gran ensayo con suero de convalecientes', La Nación, 14 Abril, viewed from https://www.lanacion.com.ar/ ciencia/coronavirus-argentina-preparan-gran-ensayo-suero-convalecientesnid2354112.

Beccaria, A., n.d., Observatorio del Conurbano, viewed n.d., from http:// observatorioconurbano.ungs.edu.ar/? $\mathrm{p}=7102$.

Bekerman, F., 2013, 'The scientific field during Argentina's latest military dictatorship (1976-1983): Contraction of public universities and expansion of the National Council for Scientific and Technological Research (CONICET)', Minerva 51(2), 253-269. https://doi.org/10.1007/s11024-013-9227-9

Bekerman, F., 2018, 'Orfología del espacio científico-universitario argentino: Una visión de largo plazo (1983-2014)', Ciencia, Docencia y Tecnolo 29(56), 18-46. https://doi.org/10.33255/2956/361

Chiroleu, A. \& Marquina, M., 2017, 'Democratisation or credentialism? Public policies', Policy Reviews in Higher Education 1(2), 139-160. https://doi.org/10.1080/23322 969.2017.1303787

Consejo Interuniversitario Nacional (CIN), 2012, Plan Estratégico de Desarrollo de la Extensión 2012-2015, Consejo Interuniversitario Nacional, Santa Fe.

CIN, 2020a, Consejo Interuniversitario Nacional, 16 Marzo, n.d., viewed from https:// www.cin.edu.ar/.

CIN, 2020b, 'Comisión especial con el Ministerio de Educación para la prevención y contención del COVID-19', in Consejo Interuniversitario Nacional, 19 Marzo, viewed n.d., from cin.edu.ar: https://www.cin.edu.ar/comision-especial-con-elministerio-de-educacion-para-la-prevencion-y-contencion-del-covid-19/

CONICET, 2020a, 'Aprueban el uso de un nuevo test molecular de COVID-19, sensible, específico, rápido y económico', in CONICET, 13 Junio, viewed n.d., from https:// www.conicet.gov.ar/aprueban-el-uso-de-un-nuevo-test-molecular-de-covid-19sensible-especifico-rapido-y-economico/

CONICET, 2020b, 'Los test de diagnóstico rápido NEOKIT-COVID-19 y ELA- CHEMSTRIP empezaron a distribuirse en los hospitales públicos', in CONICET, 29 Junio 29 , viewed n.d., from https://www.conicet.gov.ar/los-test-de-diagnostico-rapidoneokit-covid-19-y-ela-chemstrip-empezaron-a-distribuirse-en-los-hospitalespublicos/

CONICET, 2020c, 'Desarrollan telas antivirales para barbijos de uso social', in CONICET, 06 August, viewed n.d., from https://www.conicet.gov.ar/desarrollan-telasantivirales-para-barbijos-de-uso-social/. 
Dal Piva, G., 2020, 'Más de la mitad de los ingresantes universitarios abandonaron en la cuarentena', Río Negro, 03 May, viewed n.d., from https://www.rionegro.com.
ar/mas-de-la-mitad-de-los-ingresantes-universitarios-abandonaron-en-laar/mas-de-la-mitad-de-

García Delgado, D. \& Casalis, A., 2013, 'Modelo de desarrollo y universidad en Argentina. Análisis crítico y contribución de la extensión universitaria al desarrollo local y regional', +E: Revista de Extensión Universitaria 3(3), 24-31. https://doi. org/10.14409/extension.v1i3.468

Garofalo, L., 2020, 'Ventilators alone won't save us', Sapiens, 20 May.

INDEC, 2010, Censo Nacional de Población, Hogares y Viviendas 2010, Instituto Nacional de Estadísticas y Censos República Argentina, Buenos Aires.

Infobae, 2020, Coronavirus: Científicos argentinos desarrollaron un test que detecto COVID-19 hasta cuatro veces más rápido, 13 Junio, viewed n.d., from https:// www.infobae.com/salud/2020/06/13/coronavirus-cientificos-argentinosdesarrollaron-un-test-que-detecta-covid-19-hasta-cuatro-veces-mas-rapido/

Labrandero, M. \& Santander, L., 2008, ‘Extensión académica: Una función del sistema universitario', Revista de la Educación Superior 47(1), 1-10.

La Voz, 2020, 'Avanza una vacuna argentina contra Covid-19', in La Voz, 21 Junio, viewed n.d., from https://www.lavoz.com.ar/ciencia/avanza-una-vacuna-argentinacontra-covid-19

Marquina, M., 2020, 'The Argentine University against COVID-19: Old and new discussions in an unforeseen reality', International Higher Education 102, new discu.

Mendonça, M., 2020, 'Towards a deepening of labour-power differentiation: Five decades of transformation in the Argentine Higher Education System', Journal for Critical Education Policy Studies.

Mendonça, M., in press, 'Educational reform policies in Argentina in the 1970s: The beginning of a differentiation process among national universities?', Espacio, Tiempo y Educación.

Molas-Gallart, J., Salter, A., Patel, P., Scott, A. \& Duran, X., 2002, Measuring third stream activities. Final report to the Russell Group of Universities, SPRU, University of Sussex, Brighton.

Mónaco,J., 2017, 'Primera generación de estudiantes ¿Por qué yo no?', Le monde diplomatique, August, 8-9.

ONU, 2020, Análisis inicial de las Naciones Unidad. COVID-19 en Argentina: Impacto socioeconómico y ambiental, United Nations.

Página/12, 2020, 'Coronavirus: el delicado trabajo de los kinesiólogos en terapia intensiva'. Página/12, 16 Abril, viewed n.d., from https://www.pagina12.com. ar/259817-coronavirus-el-delicado-trabajo-de-los-kinesiologos-en-terap

Perfil, 2020, 'Nuevo centro de rehabilitación de la UNAHUR', Perfil, 09 August, viewed n.d., from https://www.perfil.com/noticias/educacion/nuevo-centro-derehabilitacion-de-la-unahur.phtml

Roca, A., Schneider, C. \& Pedrosa, J., 2018, El legado reformista en las nuevas universidades del conurbano: Inclusión Democracia Conocimiento, Edunpaz, José c. Paz.
Salvia, A. \& Poy, S., 2020, Presentación del estudio: Impacto social de las medidas de aislamiento obligatorio por COVID19 en el AMBA, Observatorio de la Deuda Social aislamiento obligatorio
Argentina, Buenos Aires.

Sigal, P., 2020, 'El avance de la pandemia Coronavirus en Argentina: Cómo es el acuerdo de la UBA con la medicina privada para multiplicar los donantes de plasma', Clarín, 30 Junio, viewed n.d., from clarin.com/sociedad/coronavirus-argentina-acuerdouba-medicina-privada-multiplicar-donantes-plasma_0 Q- OVsUeK.html

Suárez, A.L. \& Palma Arce, C., 2010, 'Condiciones de vida en el conurbano bonaerense', in A. Rofman (ed.), Sociedad y territorio en el conurbano bonaerense, pp. 25-102, Universidad Nacional de General Sarmiento, Buenos Aires.

Thomas, H.B., 2015, Enfoques y estrategias de desarrollo tecnológico, innovación y políticas públicas para el desarrollo inclusivo, Documentos de Trabajo IESCT-UNO, Bernal.

Tünnerman, C., 2000, 'El nuevo concepto de extensión universitaria y difusión cultural', Pensamiento Universitario 19, 2-4.

UNAHUR, 2020a, Puesta en marcha del Fondo Solidario, 29 June, viewed n.d., from http://unahur.edu.ar/es/puesta-en-marcha-del-fondo-solidario

UNAHUR, 2020b, Bici-UNAHUR: Cobertura para actividades esenciales, 28 July, viewed n.d., from http://unahur.edu.ar/es/bici-unahur-cobertura-para-actividadesviewed n.d.
esenciales

UNESCO-IESALC, 2020, COVID-19 y educación superior: De los efectos inmediatos al día después, UNESCO, viewed n.d., from http://www.iesalc.unesco.org/wpcontent/uploads/2020/05/COVID-19-ES-130520.pdf

UNGS, 2020, Fondo Solidario de emergencia social y sanitaria, 30 June, viewed n.d., from https://www.ungs.edu.ar/new/fondo-solidario-de-emergencia-social-y-sanitaria

UNPAZ, 2020, Fondo solidario UNPAZ, 07 September, viewed n.d., from https://unpaz. edu.ar/node/4153

UNQUI, 2020, 'La UNQ y la UNSAM crearon un nuevo kit de diagnóstico rápido para Covid-19', in Noticias Unqui, viewed n.d., from http://www.unq.edu.ar/ noticias/4472-la-unq-y-la-unsam-crearon-un-nuevo-kit-de-diagn $\%$ C3\%B3sticor\%C3\%A1pido-para-covid-19.php

Zamponi, A., 2020a, 'Diego Álvarez: “Desarrollamos un test que es clave para identificar donantes de plasma contra COVID19"', in Noticias UNSAM, 08 Mayo, viewed n.d.,
from http://noticias.unsam.edu.ar/2020/05/08/diego-alvarez-desarrollamos-unfrom http://noticias.unsam.edu.ar/2020/05/08/diego-alvarez-desarroll
test-que-es-clave-para-identificar-donantes-de-plasma-contra-covid19/

Zamponi, A., 2020b, 'Cómo funciona el test molecular rápido de COVID-19 100\% Argentino', in Noticias UNSAM, 14 Junio, viewed n.d., from http://noticias.unsam.edu. ar/2020/06/13/como-funciona-el-test-molecular-rapido-de-covid-19-100-argentino/

Zamponi, A., 2020c, 'Investigadores de la UNSAM desarrollaron un suero hiperinmune contra COVID-19', in Noticias UNSAM, 18 Junio, viewed n.d., from http://noticias. unsam.edu.ar/2020/06/17/investigadores-de-la-unsam-desarrollaron-un-suerohiperinmune-contra-covid-19/

Zamponi, A., 2020d, 'UNSAM y UNQ desarrollaron un diagnóstico molecular de COVID19', in Noticias UNSAM, 13 Junio, viewed n.d., from http://noticias.unsam. edu.ar/2020/06/13/unsam-y-unq-desarrollaron-un-diagnostico-molecular-decovid19/ 